\title{
The Effect of Transformational Leadership and Organizational Culture on Organizational Commitment in Mediating Organizational Cynicism
}

\author{
Prayudha Bangun Wicaksono ${ }^{1}$, Muafi $^{2}$ \\ ${ }^{1,2}$ Department of Management, Faculty of Business and Economics, Universitas Islam \\ Indonesia Yogyakarta
}

*Corresponding author. Email: muafi@uii.ac.id

OPEN ACCESS ISSN 2528-4649 (online) ISSN 2338-4409 (print)

Reviewedby: Zarah Puspitaningtyas, Irwan Moridu

${ }^{*}$ Correspondence: Muafi muafi@uii.ac.id Received: May 26, 2021 Accepted: August 9, 2021 Published: September 20, 2021 JBMP: Jurnal Bisnis, Manajemen dan Perbankan. Vol: $7 /$ No. 2 doi:10.21070/jbmp.v7vi2.1525
This study discusses and analyzes the effect of transformational leadership and organizational culture on organizational commitment mediated by organizational cynicism on employees at the Shirvano Consulting Yogyakarta company. The population and sample in this study are 31 respondents who are startup employees at Shirvano Consulting. This research uses quantitative methods by distributing questionnaires to respondents. The analytical test tool used in this study is SmartPLS v.3.0 with SEM analysis method. The results of data analysis in this study are: (1)Transformational leadership has a significant negative effect on organizational cynicism; (2)Organizational culture has no significant negative effect on organizational cynicism; (3)Organizational cynicism has a significant negative effect on organizational commitment; (4)Transformational leadership has no significant positive effect on organizational commitment; (5)Organizational culture has no significant positive effect on organizational commitment; (6)Transformational leadership has no significant positive effect on organizational commitment mediated by organizational cynicism; and (7)Organizational culture has a significant positive effect on organizational commitment mediated by organizational cynicism. Three hypotheses are accepted, while the other four hypotheses are rejected. The implication of the theory is to contribute to increase organizational commitment by considering aspects of transformational leadership and organizational culture by the mediating effect of organizational cynicism. The managerial implication is that companies or organizations can implement strategies and policies related to these four aspects.

Keywords: Transformational Leadership, Organizational Culture, Organizational Cynicism, Organizational Commitment 


\section{INTRODUCTION}

Along with advances in technology and science in the current era of globalization, competition is growing so tight. To always win the fierce competition with its competitors, the company is trying to need a power that is greater than what its competitors have. That strength comes from good internal resources. One indicator of the success of a company or agency is a good organizational commitment. Organizational commitment is defined as a situation in which an employee favors a particular organization and its goals and desires to maintain membership in the organization (Robbins and Judges, 2015). According to Porter et al. (2013), organizational commitment is the relative strength of the individual in identifying his involvement in the organization.

One of the factors that influence organizational commitment is organizational cynicism. According to Khan (2014), organizational cynicism is a negative belief or view of the organization, particularly related to destructive power, low trust in authorities and institutions, and underestimating the possibility of people ethically achieving goals. Mousa's research (2017) shows that organizational cynicism has a negative correlation with affective commitment. The results showed that organizational cynicism has a negative correlation with organizational commitment. Organizational cynicism can mediate the relationship between organizational culture and organizational commitment. That is by research conducted by Sarhana et al. (2019), which showed a significant positive effect of organizational culture on organizational commitment in which organizational cynicism acts as a mediator. Shoaib et al. (2013) found that with a good, supportive, healthy organizational culture and making employees feel they have an important role in the organization, organizational cynicism can be reduced considerable to impact the higher level of organizational commitment. However, organizational cynicism is not able to mediate the relationship between transformational leadership and organizational commitment. Novitasari (2020) shows that transformational leadership on organizational commitment mediated by organizational cynicism does not have a significant positive effect.

The next factor influencing organizational commitment is transformational leadership. Transformational leadership is a type of leader who inspires his followers to put aside their interests and has extraordinary influencing abilities (Kharis 2015). The research results by Gulluce et al. (2016) show that there is a significant positive effect between the transformational leadership scale and the organizational commitment scale. Al-Quran (2016) found that transformational leadership has a significant positive effect on organizational commitment, which impacts employees continuing to work for the company. However, Novitasari's research (2020) shows no significant positive effect of transformational leadership on organizational commitment.

Transformational leadership has a significant negative effect on organizational cynicism. Research by Terzi and Dulker (2016) has shown results that there is a significant negative effect of transformational leadership on organizational cynicism. Sirin et al. (2018) stated that the application of transformational leadership, such as providing good service to members and providing space for members to express their opinions, can reduce the level of cynicism in the organization.

Another factor that influences organizational commitment is organizational culture. Research conducted by Shoaib et al. (2013) shows that with a good, supportive, healthy organizational culture and making employees feel they have an important role in the organization, organizational commitment is also higher. However, Athar (2020) shows that a responsive and competent organizational culture does not significantly positively affect organizational commitment.

Organizational culture has a significant negative effect on organizational cynicism. The results of Sadigh's research (2016) show that when a company has a supportive, healthy, and comfortable organizational culture, it will positively impact employees, as indicated by increased organizational commitment such as creativity and involvement in decisionmaking and problem-solving. However, Yilmaz, et al. (2014) research shows that organizational culture does not significantly negatively affect organizational cynicism.

The author is interested in researching employees in startup companies. Startup companies are synonymous with innovative organizational culture. Following the characteristics of the millennial generation, the leadership style in the company is also identical with transformational leadership, where the leadership applied is more modern and flexible. However, startup companies are also synonymous with employees who have a low level of organizational commitment. According to Deloitte Indonesia Perspectives (2019) research, the average rate of the turnover employee at startup companies is above $10 \%$. That shows that there is a high level of organizational cynicism and low organizational commitment in startup companies.

The object of research that the author will carry out is an employee of Shirvano Consulting located in Yogyakarta. The reason researchers are interested in researching Shirvano Consulting is that startup companies in Yogyakarta are starting to flourish, dominated by young people in building the business, which is synonymous with transformational leadership, organizational cynicism, and an organizational culture that is different from companies that have been around for a long time.

\section{LITERATURE REVIEW}

\section{The Effect of Transformational Leadership on Organizational Cynicism}

Transformational leadership involves a deep influence relationship between people who want significant change, and the change reflects the goals shared by the leader and his followers (subordinates). Influence(influence)in this case means the relationship between leaders and followers, so that's not something passive, but it is a reciprocal relationship and without coercion. Thus, leadership itself is a process of mutual influence. 
According to Avolio and Bass (2004), transformational leadership is a leader's behavior that can activate followers' motivation and encourage them to act on that motivation for high performance. The implementation of transformational leadership is appropriate in the bureaucratic environment and various organizations with a lot of potentials and educated personnel. According to Iensufiie (2010), transformational leadership has an understanding of leadership that aims for change. The change in question is assumed to be a change that is better against the status quo and is active. Transformational leadership is also defined as a leadership approach that creates positive and valuable change for an organization. The results of research conducted by Terzi and Dulker (2018), Sadigh (2016), Şirin et al. (2018) show a significant negative correlation between transformational leadership and organizational cynicism.

H1: Transformational leadership has a significant negative effect on organizational cynicism

\section{The Influence of Organizational Culture on Organizational Cynicism}

A company must have a characteristic in carrying out its vision and mission to achieve goals, commonly called organizational culture. A company's success reflects that the company has a good organizational culture and quality and vice versa. According to Wardiah (2016), organizational culture is essentially the organization's basic values that will act as the basis for behaving, behaving, and acting for all members of the organization. Organizational culture is the way people behave in an organization. It is a set of norms consisting of beliefs, attitudes, core values, and patterns of behavior shared within the organization.

According to Sutrisno (2015), organizational culture can be defined as the system of values(value), beliefs(beliefs), assumptions(Assumptions), or norms that have long been in force, agreed upon, and followed by members of an organization as a guide to behavior and solving organizational problems.

Ergun and Kesen's (2014) research results show that organizational culture greatly influences cynicism in organizations. That is confirmed by Sadigh's research (2016), which shows a significant negative effect of organizational culture on organizational cynicism. However, study by Yilmaz et al. (2014) showed that organizational culture did not have a significant positive effect on organizational cynicism.

$\mathrm{H} 2$ : Organizational culture has a significant negative effect on organizational cynicism

\section{The Effect of Organizational Cynicism on Organizational Commitment}

Organizational cynicism is an employee's belief that the company does not have ethical principles such as fairness, honesty, and sincerity sacrificed for the organization's benefit (Atwater et al., 2011). Organizational cynicism can develop due to stress and workload, unsupportive personal expectations or organizational conditions, inadequate social support and promotions, conflicting goals, decision-making inefficiency, and communication misunderstandings. Organizational cynicism can also be caused by a salary gap between executives and employees so that employees distrust the executives and envy and dislike from employees. According to Khan (2014), organizational cynicism is a negative belief or view of the organization, particularly related to destructive power, low trust in authorities and institutions, and underestimating the possibility of people ethically achieving goals.

The results of Nafei and Kaifi (2013) research show that there is a significant negative effect of organizational cynicism on organizational commitment. Mousa's research (2017) shows that organizational cynicism has a negative correlation with organizational commitment. The research of Yüksel and ahin (2017) shows levels of organizational cynicism that lowin teachers lead to high levels of organizational commitment.

H3: Organizational cynicism has a significant negative effect on organizational commitment

\section{The Effect of Transformational Leadership on Organizational Commitment}

Leithwood and Jantzi (2003) argue that the application of the transformational leadership model is very useful for (1) building a culture of cooperation and professionalism among employees, (2) motivating leaders to develop themselves, and (3) helping Leaders solve problems effectively. The research results by Gulluce et al. (2016) showed that there was a significant positive effect between the transformational leadership scale and the organizational commitment scale. Al-Quraan research (2016) shows that transformational leadership has a significant influence on organizational commitment, which impacts employees continuing to work for the company. These results indicate that transformational leadership increases sustainable organizational commitment through the ability of leaders. The research of Khasawneh et al. (2012) shows that principals in Jordan have moderate to high levels of transformational leadership behavior so that teachers have high organizational commitment. That is different from Novitasari (2020) research, which shows no significant positive effect of transformational leadership on organizational commitment.

H4: Transformational leadership has a significant positive effect on organizational commitment.

\section{The Influence of Organizational Culture on Organizational Commitment}

According to Robbins and Judge (2015), organizational commitment is defined as a condition in which an employee favors a particular organization and its goals and desires to maintain membership in the organization. Based on this definition, members committed to the organization will remain part of the organization. Organizational commitment is a psychological state of an individual or employee related to belief, belief, and a strong acceptance of the goals and values of the organization, a strong desire to do the best for the organization, and the degree to which he has high loyalty to the organization or company. 
Research by Sarhana et al. (2019) shows that a supportive organizational culture influences organizational commitment. That is in line with research by Rastegar and Afghayan (2012), which shows the high relationship between a supportive and innovative organizational culture and organizational commitment, as evidenced by the ability of employees to demonstrate ability, talent, and the right to make decisions, which can increase organizational commitment. Shoaib et al. (2013) showed that with a good, supportive, healthy organizational culture and making employees feel they have an important role in the organization, organizational commitment is also higher. However, Athar's research (2020) shows that a responsive and competent organizational culture does not have a significant positive effect on organizational commitment.

H5: Organizational culture has a significant positive effect on organizational commitment

\section{The Effect of Transformational Leadership on Organizational Commitment Mediated by Organizational Cynicism}

Research Results Al-Qur'an (2016) shows an influence of transformational leadership on organizational commitment in which organizational cynicism mediates. With the applied transformational leadership, the level of organizational cynicism in Jordan Ahli Bank's company is very low, which then causes organizational commitment to become better. Khasawneh et al. (2012) and Gulluce et al. (2016) found a significant positive effect of transformational leadership on organizational commitment mediated by organizational cynicism. However, Novitasari (2020) research shows that transformational leadership on organizational commitment mediated by organizational cynicism does not have a significant positive effect.

H6: Transformational Leadership significant positive effect on the organizational commitment that is mediated by organizational cynicism

\section{Organizational Cultural Influence of Organizational Commitment Against The Mediated By Organizational Cynicism}

The results Sarhana et al. (2019) show the influence of organizational culture on organizational commitment in which organizational cynicism acts as a mediator. That is supported by Shoaib et al. (2013), showing that organizational cynicism mediates the influence of organizational culture on organizational commitment. A good, supportive, healthy organizational culture and making employees feel they have an important role in the organization can reduce organizational cynicism considerably to impact the higher level of organizational commitment. Rastegar and Aghayan (2012) show that a good organizational culture can make employees feel that they have the right to reduce the level of organizational cynicism.

H7: Organizational Culture has a significant positive effect on organizational commitment mediated by organizational cynicism.

\section{METHOD (FOR RESEARCH ARTICLE)}

This study uses a quantitative approach. Quantitative research is a systematic, structured, and planned research from the beginning to the end of the research. The purpose of doing quantitative research is to determine the relationship between one variable and another variable in a population. In the study included in the research, the population is all employees who work at Shirvano Consulting. Total population of 31 people. The sampling technique used a census so that the number of samples that became respondents in this study included all employees at Shirvano Consulting, namely 31 people. The data taken in this study were through questionnaires distributed to respondents with the criteria mentioned above to obtain direct data on transformational leadership, organizational culture, organizational cynicism, and organizational commitment. Variable measurements were carried out using a Likert scale of 1-5. The data analysis technique used in this study uses PLS-SEM. PLS-SEM analysis consists of two sub-models: the structural or inner model and the measurement or outer model.

This study involves four variables consisting of 3 exogenous variables and one endogenous variable. The following is the operational definition of each variable:

\section{Transformational Leadership}

According to Edison et al. (2016), transformational leadership inspires their followers to believe in themselves and believe in their potential to envision and create a better future for the organization. Measurement of transformational leadership refers to Avolio et al. (1999).

\section{Organizational Culture}

According to Wardiah (2016), organizational culture is essentially the organization's basic values, which will act as the basis for attitude, behavior, and action for all members of the organization. The measurement of organizational culture in this study refers to the opinion of McShane and Von Gilnov (2005).

\section{Organizational Cynicism}

According to Khan (2014), organizational cynicism is a negative belief or view of the organization, particularly related to destructive power, low trust in authorities and institutions, and underestimating the possibility of people achieving goals in an ethical way. The indicator of organizational cynicism refers to the opinion of Nafei (2013).

\section{Organizational Commitment}

According to Robbins and Judge (2011), organizational commitment is defined as a condition in which an employee favors a particular organization and its goals and desires to maintain membership in the organization. Measurement of organizational commitment refers to the opinion of Allen and Meyer (1997).

\section{RESULTS AND DISCUSSION}

\section{Description of Respondents}

Respondents studied based on gender, female respondents amounted to 16 people $(51.6 \%)$, while the rest 
were men with a total of 15 respondents $(48.4 \%)$. Based on the age of the respondents, the majority are respondents aged 20 - 30 years with a total of 28 respondents $(90.3 \%)$, age less than 20 with two respondents (6.5\%), age 41-50 with one respondent $(3.2 \%)$. Based on the latest education, the majority are Bachelors (S1) with a total of 19 respondents $(61.3 \%)$, high school level with ten respondents $(32.3 \%)$, diploma level with one respondent (3.2\%), and postgraduate level with one respondent (3.2\%).

\section{Descriptive Variable}

The results of the validity and reliability test resulted in all valid and reliable items. The transformational leadership variable (x1) with a total average of 4.10 is included in the high category. The organizational culture variable $(\mathrm{x} 2)$ with a total average of 3.9 is included in the high category. The variable organizational cynicism (y) with a total average of 1.9 is included in the low category. The organizational commitment variable ( $\mathrm{z}$ ) with a total average of 3.43 is included in the high category. From these results, the researcher concludes that the Shirvano Consulting company has a high level of transformational leadership, organizational culture, and organizational commitment and a level of organizational cynicism low.

\section{Results Hypothesis Test}

The results of the relationship test between variables can be seen in Figure 1 below:

[Figure 1 about here.]

The results of the structural model analysis can be seen in Table 1 below:

[Table 1 about here.]

Based on the results of structural testing, Table 1 shows that the three items are significant to the dimensions of the construction with an at-statistical value $>1.96$ and a $p$-value $<0.05$. However, four items are not significant to the construction dimensions because of the t-statistic value $<1.96$ and p-value $>0.05$.

\section{Discussion}

\section{The Effect of Transformational Leadership on Organizational Cynicism}

Based on the data processing results, it can be seen that transformational leadership negatively affects organizational cynicism. That can be seen from the original sample value of -0.490 , which means it has a negative relationship. The $\mathrm{t}-$ statistic value of this construction relationship is 2.681 , and the p-value is 0.008 , so it can see that the relationship between transformational leadership and organizational cynicism is significantly negative. (The first hypothesis is accepted).
The results of this study indicate that transformational leadership has a significant negative effect on organizational cynicism. That means that when leaders in a company apply transformational leadership, it will reduce the chances of organizational cynicism. The higher the level of transformational leadership, the lower the level of organizational cynicism and vice versa. This shows a need for the development of transformational leadership applied by the leadership to employees at Shirvano Consulting. Among them are conducting open communication, establishing good personal relationships with employees, and providing opportunities for employees to express ideas for the company's progress.

These results follow the research conducted by Terzi and Dulker (2018), where there is a relationship between the influence of transformational leadership and organizational cynicism. This study indicates a negative correlation between transformational leadership and organizational cynicism, where organizational cynicism will decrease when the influence of transformational leadership is strong. These results are in line with research conducted by Sadigh (2016), where when leaders in companies apply transformational leadership, it will positively impact employees as indicated by increased creativity, involvement in decision-making, and mass solving. These results are also in line with research conducted by irin et al. (2018), where the application of transformational leadership, such as providing good service to members, providing space for members to have opinions and a shared sense of belonging to the organization can reduce the level of cynicism in the organization.

\section{Effect of Organizational Culture on Organizational Cynicism}

Based on the data processing results, it can be seen that organizational culture negatively influences organizational cynicism. That can be seen from the original sample value of -0.397 , which means it has a negative relationship. However, the t-statistic value of this construction relationship is 1.887 , and the p-value is 0.060 so that it can see that the relationship between organizational culture and organizational cynicism is not significantly negative (second hypothesis is rejected).

The results of this study indicate that organizational culture has a negative and insignificant effect on organizational cynicism. This means that the Shirvano Consulting company has a good, supportive, and comfortable organizational culture but does not affect the level of organizational cynicism. Thus, it is hoped that Shirvano's company can maintain and improve organizational cultural values to employees by providing a comfortable working atmosphere, providing space for joint discussions, implementing a working system that is following employee characteristics, and always involving employees in important decisions in the company.

The results of this study follow research conducted by Yilmaz et al. (2014), where organizational culture does not significantly affect organizational cynicism. Organizational culture and academic achievement have no significant effect on organizational cynicism. 
The results of this study are not following the research conducted by Ergun and Kesen (2014), where organizational culture greatly influences the cynicism in the organization. Ergun and Kesen (2014) argue that organizational culture helps organizations generate creative outputs and obtain new opportunities. This study's results do not follow Sadigh's (2016) research where there is a relationship between the influence of organizational culture and organizational cynicism. Sadigh (2016) argues that when a company has a supportive, healthy, and comfortable organizational culture, it will positively impact employees, as indicated by increased creativity, decision-making, and problem-solving involvement. The results of this study do not follow research conducted by Prajogo and Wijaya (2020), where a supportive organizational culture positively influences work. A supportive organizational culture has a positive influence on employees' affective responses to organizational change. Third, the affective response of employees to organizational change has a negative effect on organizational cynicism.

\section{Effect of Organizational Cynicism Organizational Commitment}

Based on the results of data processing, it can see that organizational cynicism negatively affects organizational commitment. It can be seen from the original sample value of -0.746 , which means it has a negative relationship. The tstatistic value of this construction relationship is 3.298, and the p-value is 0.001 . It can be seen that there is a significant negative relationship between organizational cynicism and organizational commitment. (The third hypothesis is accepted).

The results of this study indicate that organizational cynicism has a significant negative effect on organizational commitment. That means that when organizational cynicism is low, it gives rise to employee involvement, growing innovation, good relations between employees, and higher employee loyalty to the company. That shows a low level of organizational cynicism in Shirvano Consulting employees, thus creating a sense of solidarity and good relations between employees. This affects the high level of organizational commitment. Thus the need for good teamwork, mutual support between employees, helping each other in solving problems. So that it can reduce the level of organizational cynicism.

These results are following the research conducted by Yüksel and ahin (2017) where this study shows levels of organizational cynicism that lowin teachers lead to high levels of organizational commitment. It is proven by the involvement of teachers, high levels of innovation, good relations between teachers, and low levels of organizational cynicism so that organizational commitment is high. That is in line with Mousa's research (2017) where this study shows that organizational cynicism has a negative correlation with organizational commitment. A level of organizational cynicism low will increase organizational commitment in the company. This result is also in line with Nafei and Kaifi (2013) research, where this study shows that there is a statistically negative effect between the dimensions of organizational cynicism on organizational commitment.

\section{The Effect of Transformational Leadership Organizational Commitment}

Based on the results of data processing, it can see that transformational leadership positively influences organizational commitment. That can be seen from the original sample value of 0.100 , which has a positive relationship. However, the $t$-statistic value of this construction relationship is 0.488 , and the p-value is 0.626 , so it can be seen that there is no significant positive relationship between transformational leadership and organizational commitment. (The fourth hypothesis is rejected).

Based on the results of the fourth hypothesis, the authors advise all employees of the Shirvano Consulting company, namely the need for increased cooperation between employees, understanding the company's vision and mission, and good transparency between leaders and employees Shirvano Consulting. Thus, it can create good interactions and maximum work results to foster good organizational commitment.

This study's results follow research conducted by Novitasari (2020), where the effect of transformational leadership on organizational commitment is not significantly positive. The leadership carried out by the leadership does not affect the organizational commitment of teachers and employees. That is evidenced by the influence of ideal, inspirational motivation and individual considerations have no significant effect on organizational commitment.

The results in this study are not in accordance with the research conducted by Gulluce et al (2016), where there is a significant positive effect between the transformational leadership scale and the organizational commitment scale. The results of this study are not in accordance with research conducted by Al-Quraan (2016), where transformational leadership has a significant influence on organizational commitment and this has an impact on employees continuing to work for the company. Al-Quraan (2016) found that transformational leadership sustained increase organizational commitment through the ability of the leaders. This result is also inconsistent with research conducted by Khasawneh et al. (2012), where principals in Jordan have moderate to high levels of transformational leadership behavior so that teachers have high organizational commitment.

\section{The Effect of Organizational Culture on Organizational Commitment}

Based on the data processing results, it can see that organizational culture has a positive influence on organizational commitment. That can be seen from the original sample value of 0.003 , which means it has a positive relationship. However, the t-statistic value of this construction relationship is 0.012 , and the p-value is 0.990 . It can be seen that there is no significant positive relationship between organizational culture and organizational commitment (the fifth hypothesis is rejected). The positive influence in this relationship can be interpreted that the higher the level of organizational culture, the higher the level of organizational commitment in the company. 
The results of this study indicate that organizational culture has no positive and insignificant effect on organizational commitment. That proves that the organizational culture that exists at Shirvano Consulting does not have a significant effect on organizational commitment. It is hoped that the Shirvano company can maintain and improve organizational cultural values to employees by providing a comfortable working atmosphere, providing space for joint discussions, implementing a working system following employee characteristics, and always involving employees in important decisions in the company.

These results follow research conducted by Athar (2020), where a responsive and competent organizational culture does not significantly affect organizational commitment. This result does not follow the research conducted by Shoaib et al. (2013), where a good, supportive, healthy organizational culture makes employees feel they have an important role in the organization, the higher the level of organizational commitment. This study's results do not follow the research conducted by Sarhana et al. (2019), where a supportive organizational culture influences organizational commitment. The results of this study are also not following research conducted by Rastegar and Afghayan (2012), where there is a high relationship between a supportive and innovative organizational culture and organizational commitment.

\section{The Effect of Transformational Leadership on Organizational Commitment Mediated by Organizational Cynicism}

Based on the data processing results, it can be seen that transformational leadership positively influences organizational commitment mediated by organizational cynicism. That can be seen from the original sample value of 0.366, which means it has a positive relationship. However, the t-statistic value of this construction relationship is 1.906 , and the p-value is 0.057 . It can be seen that there is no significant positive relationship between transformational leadership and organizational commitment mediated by organizational cynicism (the sixth hypothesis is rejected).

This study explains that organizational cynicism cannot mediate the relationship of transformational leadership to organizational commitment. Therefore, it can conclude that the high level of transformational leadership leaders at Shirvano Consulting does not significantly affect organizational commitment. Thus, it is necessary to develop the transformational leadership applied by the leadership to the employees at Shirvano Consulting. Among them are conducting open communication, establishing good personal relationships with employees, and providing opportunities for employees to express ideas for the company

This study's results follow research conducted by Novitasari (2020), where the effect of transformational leadership on organizational commitment is not significantly positive. This study's results do not follow research conducted by Al-Quraan (2016), where organizational cynicism mediates the effect of transformational leadership on organizational commitment. With the applied transformational leadership, the level of organizational cynicism in the company is very low, which then causes organizational commitment to become better. This result is not following the research conducted by Gulluce et al. (2016), where organizational cynicism mediates the effect of transformational leadership on organizational commitment. So it can conclude that the level of organizational commitment can be high if transformational leadership is applied.

\section{The Effect of Organizational Culture on Organizational Commitment is Mediated by Organizational Cynicism.}

Based on the data processing results, it can see that organizational culture positively influences organizational commitment mediated by organizational cynicism. It can be seen from the original sample value of 0.296 , which means it has a positive relationship. The t-statistic value of this construction relationship is 2.150 , and the p-value is 0.032 . It can be seen that there is a significant positive relationship between organizational culture and organizational commitment mediated by organizational cynicism (the seventh hypothesis is accepted).

This study explains that organizational cynicism can mediate the relationship of organizational culture to organizational commitment. Therefore it can conclude that the high organizational culture of the Shirvano Consulting company affects organizational cynicism low so that it has a significant positive effect on organizational commitment. It is hoped that the Shirvano company can maintain and improve organizational cultural values to employees by providing a comfortable working atmosphere, providing space for joint discussions, implementing a working system following employee characteristics, and always involving employees in important decisions in the company.

This study's results follow research conducted by Sarhana et al. (2019), where organizational culture influences organizational commitment and organizational cynicism as a mediator. These results indicate that organizational culture can reduce organizational cynicism and increase sustainable organizational commitment through a well-organized organizational culture. This study results follow research conducted by Shoaib et al. (2013), which shows that organizational cynicism mediates the influence of organizational culture on organizational commitment. These results also follow research conducted by Rastegar and Aghayan (2012), showing that a good organizational culture can make employees feel that they have their rights so that organizational cynicism can be reduced and affect organizational commitment.

\section{CONCLUSIONS}

Based on the results of data analysis and discussion, several conclusions can be drawn as follows: (1) Transformational leadership has a significant negative effect on organizational cynicism, (2) Organizational culture has no significant negative effect on organizational cynicism, (3) Organizational cynicism has a significant negative effect on organizational commitment, (4) transformational leadership has no significant positive effect on organizational 
commitment, (5) organizational culture has no significant positive effect on organizational commitment, (6) Transformational leadership has no significant positive effect on organizational commitment mediated by organizational cynicism, (7) Organizational culture has a significant positive effect on organizational commitment mediated by organizational cynicism. The limitation of this research is that this research was conducted during the Covid-19 pandemic, so that many employees work from home. The practical implications of this research are expected to provide information and knowledge about the level of influence of transformational leadership and organizational culture on organizational commitment mediated by organizational cynicism. 


\section{REFERENCES}

A, Morissan. (2014). Metode Penelitian Survei. Cet-2. Jakarta: Kencana.

Abdullah, W, H. (2015). Partial Least Square (PLS). Penerbit Andi. Yogyakarta.

Abraham, R. (2000). Organizational cynicism: Bases and consequences. Genetic, Social \& General Psychology Monographs. $126(3), 269-92$.

Afnan, E., Rini, R., Nafita, S., \& Armanu. (2016). Pengaruh Kepuasan Kerja dan Komitmen Organisasional Terhadap Intention to Leave Pada Karyawan Produksi Mitra Produksi Sigaret (MPS) Ngoro_Jombang. Jurnal Bisnis dan Manajemen, 3 (1), 54-64

Aghayan \& Rastegar. (2012). Impacts of Organizational Culture on Organizational Commitment. Journal of Human Resource Management and Development (JHRMD). 2 (2), 1-13.

Allen \& Meyer. (1991). The Measurement and Antecedents of Affective, Continuance and Normative Commitment to the Organizational. Journal of Occupational Psychology. 63 (1), 1- 18.

Allen \& Meyer. (1997), Commitment in The Workplace: Theory Research and Application. California: Sage Publications

Al-Quraan. (2016). Impact of Transformational Leadership on Organizational Commitment : Case Study at Jordan Ahli Bank. European Journal of Business and Management. 8 (31), 145-156

Anderson, LM, \& Bateman, TS (1997). Cynicism in the workplace: Some causes and effects. Journal of Organizational Behavior. 18 (5), 449-469.

Athar. (2020). The Influence of Organizational Culture on Organizational Commitment Post Pandemic Covid-19. International Journal of Multicultural and Multireligious Understanding. 7 (5), 148-157

Atwater, LE, Waldman, DA, Atwater, D., \& Cartier, P. (2000). An Upward Feedback Field Experiment: Supervisors' Cynicism, Reactions and Commitment to Subordinates. Personnel Psychology. 53(2), 275-297.

Avolio., Bruce J., Bersona., \& Yair. (1999), Transformational Leadership and The Dissemination of organizational Goals: A Case Study of Telecommunication Firm. The Leadership Quarterly. 15 (4), 625-646.

Badeni. (2013). Kepemimpinan \& Perilaku Organisasi (edisi kesatu). Bandung: Alfabeta.

Bass, B. (2006). Transformational Leadership. London: Lawrence Erlbaum Associates.

Bungin, B. (2005). Metode Penelitian Kuantitatif. Jakarta: Prenadamedia.

Chin, W, W. (1998). The Partial Least Squares Approach to Structural Equation Modeling. Dalam GA Marcoulides, Modern Methods For Business Research (hal. 295-336). London: Lawrence Erlbaum Associates

Colquitt, J, A., LePine, J, A., \& Wesson, M, J. (2009). Organizational behavior: Improving performance and commitment in the workplace. United States: McGraw-Hill

Daniels, T, D \& Qian, Y. (2008). A communication model of employee cynicism toward organizational change. Corporate Communications An International Journal. 13 (3), 319-332.

Dean, J., Brandes, P., \& Dharwadkar, R. (1998). Organizational cynicism.The Academy of Management Review. 23 (2), $341-352$.

Decelles, K., Faye, T., \& Paul, E. (2013). A Field Investigation of Multilevel Cynicism Toward Change. Organization Science. 24 (1), 154-171.

Delken, M. (2004). Organizational cynicism: A study among call centers; A thesis submitted in partial fulfillment of the requirements for the degree of Master of Economics University of Maastricht.

Duli, N. (2019). Metodologi Penelitian Kuantitatif: Beberapa Konsep Dasar Untuk Penulisan Skripsi \& Analisa Data dengan SPSS. Yogyakarta: Grup Penerbitan CV BUDI UTAMA

Edy, S. (2015). Budaya Organisasi. Jakarta: Prenada Media.

Ghozali, I. (2012). Aplikasi Analisis Multivariate dengan Program IBM SPSS. Yogyakarta: Universitas Diponegoro. 
Ghozali, I. (2014). Structural Equation Modelling, Metode Alternatif Dengan PLS. Semarang: Diponegoro University Publishing Agency.

Gujarati, D. (2004). Basic Econometrics (Ekonometrika Dasar). Jakarta: Penerbit Erlangga.

Gulluce, E, K., Sultan, BK, \& Metin, A. (2016). The Relationship between Transformational Leadership and Organizational Commitment: A Study on the Bank Employees. Journal of Service Science and Management. 9 (3), 263-275.

Gulluce. (2018). The Relationship between Transformational Leadership and Organizational Commitment: A Study on the Bank Employees. Educational Management Administration \& Leadership. 40(4) 494-508.

Hair, JF, Sarstedt, M., \& Ringle, M. (2011). PLS - sem: Indeed a silver bullet. The Journal of Marketing Theory and Practice. 19 (2), $139-151$.

Hartog \& De, J. (1997). How leaders influence employees innovative behaviour. European Journal of Innovation Management. 10(1), 41-64

Hasibuan, M, S, P. (2013). Manajemen Dasar, Pengertian, dan Masalah,Edisi Revisi. Jakarta: Bumi Aksara.

Herlina, V. (2019). Panduan Praktis Mengolah Data Kuesioner Menggunakan SPSS. Jakarta: Elex Media Komputindo.

Hikmawati, F. (2017). Metodologi Penelitian. Depok: Rajawali Pers

Iensufiie, T. (2010). Leadership Untuk Profesional dan Mahasiswa. Jakarta: Erlangga

Jantzi, L. (2003). Transformational Leadership. Philadelphia: Open University Press.

Kendra, C. (2013), "What is Transformational Leadership? How Transformasional Leadership Inspire”. About.com Guide. (Diakses pada tanggal 10 Desember 2020). http://psychology.about.com/od/leadership/a/transformational.htm

Kesen, M., \& Ergun, E. (2014). The Effects of Human Resource Management Practices and Organizational Culture Types on Organizational Cynicism: An empirical study in Turkey. British Journal of Arts and Social Sciences. 17 (I), $1659-1670$.

Khan, M, A. (2014). Organizational cynicism and employee turnover intention: Evidence from banking sector in Pakistan. Pakistan Journal of Commerce and Social Sciences. 8. (1), 30-41.

Kharis. (2015). Pengaruh Gaya Kepemimpinan Transformasional Terhadap Kinerja Karyawan Dengan Motivasi Kerja Sebagai Variabel Intervening (Studi Pada Karyawan Bank Jatim Cabang Malang). Jurnal Administrasi Bisnis (JAB). 3 (1), 1-9.

Khasawneh, S., Aieman, O., \& Abdullah, M. (2012). The Relationship Between Transformational Leadership and Commitment: The Case for Vocational Teachers in Jordan, Educational Management Administration \& Leadership. 40 (4), 494 508 .

Khoirusmadi. (2011). Analisis Pengaruh Kepemimpinan Transformasional terhadap Kinerja Pegawai dengan Budaya Organisasi sebagai Variabel Interventing (Studi pada Sekretariat Daerah Pemerintah Kota Pekalongan). Skripsi Manajemen. Fakultas Ekonomi. Diponegoro University. Semarang

Konakli, T., Gökçe, Ö., \& Salih, Ç. (2013). Impact of school managers 'altruist behaviors upon organizational cynicism: The case of Kocaeli, Turkey. Academic Journal. 8 (24), 2317-2324

Kreitner, R., \& Kinicki, A. (2001). Organizational Behavior. New York: McGraw-Hill Higher Education.

Lund, D, B. (2003). Organizational Culture and Job Satisfaction, Journal of Business \& Industrial Marketing. 18 (3), 219 236.

Luthans, F. (2006). Perilaku Organisasi Edisi 10 Bahasa Indonesia. Penerbit Andi: Yogyakarta.

Mas'ud, F. (2004). Survey Diagnosis Organisasional. Semarang: Diponegoro University Publishing Agency.

Mathis, J. (2015). Human Resources Management. USA: Cengange Learning.

McShane, S, L., \& Von G, M, A. (2005). Organizational Behavior.3e. McGraw Hill - Irwin.

Mousa. (2017). Organizational Cynicism and Organizational Commitment in Egyptian Public Primary Education: When Spring Yields Black Flowers. Arabian Journal of Business and Management Review. 6 (9), 4-19.

Mowday, RT, Porter, LW, \& Steers, RM (2010). Employee-Organization Linkages. Texas: South-Western Cengage Learning. 
Nafei. (2013). Examining the Relationship between Organizational Cynicism and Organizational Change: A Study from Egyptian Context. Journal of Business Administration Research. 2 (2), 1-12.

Netemeyer, R, G., Boles, J, S., \& McMurrian, R. (1996). Development and validation of work-family conflict and familywork conflict scales. Journal of Applied Psychology. 81(4), 400- 410.

Notoatmodjo, S. (2010). Metodologi Penelitian Kesehatan. Jakarta: Rineka Cipta.

Novitasari. (2020). Improving Job Satisfaction and Organizational Commitment: Analysis of the Effects of the Principal Transformational Leadership. Dinamika Pendidikan. 15 (2) 172-189

O'Leary, E. (2001). Kepemimpinan. Edisi Pertama. Yogyakarta: Andi.

Özler, E, D., Atalay, G, C., \& Şahin, D, M., (2010). “Örgütlerde Sinizm Güvensizlikle Mi Bulaşır?”, Organizasyon ve Yönetim Bilimleri Dergisi. 2(2), 47-57.

Reichers, A, E., Wanous, J, P., \& Austin, J, T. (1997). Understanding and Managing Cynicism about Organizational Change. The Academy of Management Executive. 11 (1), 48-59.

Rivai, V., \& Mulyadi, D. (2012), Kepemimpinan dan Perilaku Organisasi. Edisi Ketiga. Jakarta: PT. Raja Grafindo Persada

Robbins \& Judge. (2011). Perilaku Organisasi (Edisi 12). Jakarta: Salemba Empat

Robbins, S, P. (2013). Perilaku Organisasi Edisi 10. Jakarta: PT Indeks Kelompok Gramedia.

Robert, K., \& Angelo, K. (2017). Organizational Behavior. Seventh Edition. McGraw-Hill.

Sadigh. (2016). The effect of transformational leadership style and organizational culture on the formation of organizational cynicism in the Agricultural Bank of Tehran. Iran: Management Science Letters. 6 (4), 443-545.

Sahini, S., \& Yüksel. (2017). The Relationship Between Organizational Cynicism and Organizational Commitment. European Journal of Education Studies. 3 (8), 289-311.

Sana, R., Akhtar, S., Naseer, Z., \& Haider, M. (2013). Impact of Organizational Culture on Organizational Commitment: A Comparative Study of Public and Private Organizations. Research Journal of Recent Sciences. 2 (5), 1-8.

Sarhana, N., Ayman, H., Fayiz, S., \& Mohammad, A. (2019). The effect of organizational culture on the organizational commitment: Evidence from hotel industry. Management Science Letter. 10 (1), 183-196.

Schermerhorn., Osborn., Hunt., \& Uhl-Bien. (2011). Organizational Behavior. USA : Wiley.

Sekaran, U. (2011). Research Methods For Business (Metode Penelitian Untuk Bisnis). Jakarta: Salemba Empat.

Sheela, R, C., \& Vohra, N. (2016). Relationship between perceptions of corporate social responsibility and organizational cynicism: the role of employee volunteering. The International Journal of Human Resource Management. 27 (13), $1373-1392$.

Shirvano. (2019). Membangun Shirvano. https://medium.com/life-at-shirvano/membangun-shirvano-68eb77d50cea (diakses pada tanggal 11 Desember 2020)

Shoaib, C., Akhtar., \& Zainab, N. (2013). Impact of Organizational Culture on Organizational Commitment: A Comparative Study of Public and Private Organizations. Research Journal of Recent Sciences. 2 (5), 1-8.

Sirin, Y, E., Özge, A., \& Fatma, P, B. (2018). Transformational-Transactional Leadership and Organizational Cynicism Perception: Physical Education and Sport Teachers Sample. Universal Journal of Educational Research. 6 (9), $2008-2018$.

Soetopo. (2012). Perilaku Organisasi. Bandung : Remaja Rosdakarya.

Suana, I, W., \& Mustikawati, R. (2018). Pengaruh Sinisme Organisasi dan Keadilan Organisasi Terhadap Komitmen Organisasional. 7 (5), 2380-2409.

Sugiyono. (2016). Metode Penelitian Pendidikan. CV Alphabeta, Bandung.

Suryani, E., \& Novita, A. (2018). Pengaruh Gaya Kepemimpinan Transformasional dan Budaya Organisasional Terhadap Kinerja Karyawan Melalui Kepuasan Kerja Sebagai Variabel Intervening. E-Jurnal Manajemen Universitas Udayana. 13 (2), 274-295.

Susanto, H., \& Nuraini, A. (2010). Analisis Pengaruh Kepemimpinan dan Budaya Kerja dengan Motivasi Sebagai Variabel Intervening Terhadap Kinerja Karyawan di Kantor Pertanahan Kabupaten Kebumen. Magistra. 74 (22), 35-37. 
Sutrisno, E. (2010). Budaya Organisasi. Jakarta: Kencana.

Terzi, A, R., \& Dulker, A, P. (2016). An Analysis Of The Relationship Between Transformational Leadership and Organizational Cynicism. Universal Journal of Educational Research. 7 (9), 437-451.

Thomas, J, R., \& Nelson. (2010). Research Methods in Physical Activity. Human Kinetics.

Wageeh \& Kaifi. (2013). The Impact of Organizational Cynicism on Organizational Commitment: An applied Study on Teaching Hospitals in Egypt. European Journal of Business and Management. 6 (12), 131-147.

Wahidah, S. (2018). Analisis Pengaruh Gaya Kepemimpinan, Disiplin Kerja dan Lingkungan Kerja Terhadap Kinerja Pegawai di Kantor Kecamatan Kabupaten Bantaeng. Jurnal Mirai Management. 3 (1), 1-15.

Wardiah, M, L. (2016). Teori Perilaku dan Budaya Organisasi. Colomadu : Pustaka Setia.

Wijaya, N, H, S., Wisnu, P., \& Heni, K. (2020). Organizational Culture as Determinant of Employee Based Antecedents to Organizational Cynicism. Humanities \& Social Sciences Reviews. 8 (1), 881-886.

Yilmaz, D, E, K., \& Gökhan, K. (2014). Organizational Cynicism, School Culture, and Academic Achievement: The Study of Structural Equation Modeling. Educational Sciences: Theory \& Practice. 14 (1), 102-113.

Yüksel, H., \& Şahini, Ş. (2017). The Relationship Between Organizational Cynicism and Organizational Commitment. European Journal of Education Studies. 3 (8), 289-311.

Conflict of Interest Statement: The authors declare that the research was conducted in the absence of any commercial or financial relationships that could be construed as a potential conflict of interest.

Copyright (C) tahun terbit nama belakang and nama belakang. This is an openaccess article distributed under the terms of the Creative Commons Attribution License (CC BY). The use, distribution or reproduction in other forums is permitted, provided the original author(s) and the copyright owner(s) are credited and that the original publi-cation in this journal is cited, in accordance with accepted academic practice. No use, distribution or reproduction is permitted which does not comply with these terms. 


\section{LIST OF FIGURES}

1 Outer Model Test Results.

207 


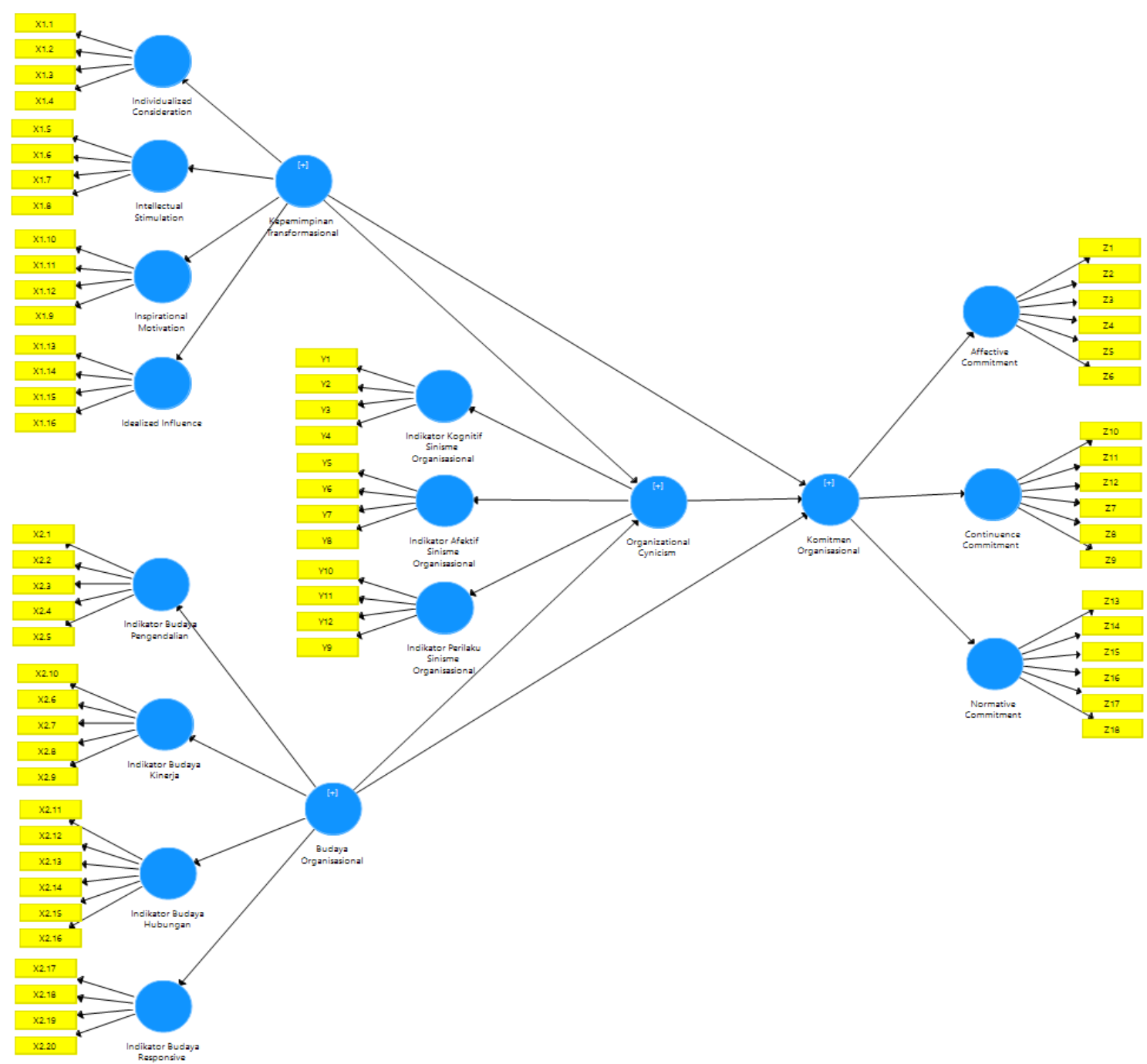

Figure $1 \mid$ Outer Model Test Results 


\section{LIST OF TABLES}

1 Structural Model Test Results 
TABLE 1 | Structural Model Test Results

\begin{tabular}{|l|c|c|c|c|}
\hline \multicolumn{1}{|c|}{ Research Variable Relationship } & Original Sample & T Statistics & P Value & Hipotesis \\
\hline $\begin{array}{l}\text { Transformational Leadership > } \\
\text { Organizational Cynicism }\end{array}$ & -0.490 & 2.681 & $0.008^{*}$ & $\mathrm{H} 1$ accepted \\
\hline $\begin{array}{l}\text { Organizational Culture > Organizational } \\
\text { Cynicism }\end{array}$ & -0.397 & 1.887 & 0.060 & $\mathrm{H} 2$ rejected \\
\hline $\begin{array}{l}\text { Organizational Cynicism > } \\
\text { Organizational Commitment }\end{array}$ & -0.746 & 3.298 & $0.001^{*}$ & $\mathrm{H} 3$ accepted \\
\hline $\begin{array}{l}\text { Transformational Leadership > } \\
\text { Organizational Commitment }\end{array}$ & 0.100 & 0.488 & 0.626 & $\mathrm{H} 4$ rejected \\
\hline $\begin{array}{l}\text { Organizational Culture > Organizational } \\
\text { Commitment }\end{array}$ & 0.003 & 0.012 & 0.990 & $\mathrm{H} 5$ rejected \\
\hline $\begin{array}{l}\text { Transformational Leadership > } \\
\text { Organizational Cynicism > } \\
\text { Organizational Commitment }\end{array}$ & 0.366 & 1.906 & 0.057 & $\mathrm{H} 6$ rejected \\
\hline $\begin{array}{l}\text { Organizational Culture > Organizational } \\
\text { Cynicism > Organizational Commitment }\end{array}$ & 0.296 & 2.150 & $0.032^{*}$ & $\mathrm{H} 7$ accepted \\
\hline
\end{tabular}

Note $^{*}:$ Sig $<0,05$

Sources: Primary data processed 2021 